\title{
Human papillomavirus in oesophageal squamous cell carcinoma
}

\author{
S L Loke, L Ma, M Wong, G Srivastava, I Lo, C C Bird
}

\begin{abstract}
Thirty seven cases of oesophageal squamous cell carcinoma were studied by applying DNA slot blot analysis and in situ hybridisation using type specific probes for HPV 6, 11, 16 and 18. Cases of condyloma accuminata, cervical carcinoma, and laryngeal papilloma were used as controls. Blocks including areas of invasive carcinoma, intraepithelial neoplasia, and normal epithelium were studied in each case. No HPV genome was detectable in any of the oesophageal cases. It is concluded that these types of HPV do not have an association with oesophageal squamous cell carcinoma.
\end{abstract}

Human papillomavirus (HPV) infection is associated with the development of papillomas or condylomas in various parts of the body, ${ }^{1-4}$ and HPV types 6 and 11 are most frequently found in such benign lesions. ${ }^{5} \mathrm{HPV}$ infection has also been confirmed in oesophageal papillomas by the presence of koilocytic features, ${ }^{6}$ viral antigen, ${ }^{7}$ or viral genome. ${ }^{8}$ There is also a suggestion that HPV infection of the oesophagus is on the increase. ${ }^{9}$

The recent detection of the HPV genome in cervical squamous cell carcinoma has prompted the search for virus in squamous cell carcinomas (SCC) in other sites of the body. HPV types 16 and 18 are most frequently detected in these malignant lesions and their association with malignancy seems to be relatively independent of site. ${ }^{3410}$ While there are a few reports suggesting that HPV is detectable in oesophageal SCC, ${ }^{11-14}$ this has not been confirmed in other studies. ${ }^{4}$

To investigate this possibility further we applied in situ hybridisation and DNA slotblot analysis to a series of oesophageal SCC occurring in Hong Kong. The former technique proved sufficiently sensitive to detect $\mathrm{HPV}$ in cervical SCC ${ }^{15}$ where tumour cells are likely to contain many copies of viral genome. DNA slot-blot analysis, however, can detect virus where the genomic copies are low.

Queen Mary Hospital, Hong Kong

$\mathrm{L} M \mathrm{a}$

M Wong

G Srivastava

I Lo

Department of

Pathology, University of Edinburgh,

Scotland

C C Bird

Correspondence to: Dr S L Loke

Accepted for publication

6 July 1990

Thirty seven cases of oesophageal SCC where total oesophagectomy had been performed were selected for study. These included a selection of 14 cases with multiple separate primary tumours in the oesophagus. The whole specimen in each case had been totally embedded for histological examination to intraepithelial neoplasm. DNA was extracted from the tumour in 21 of these cases before wax embedding. For each case, blocks representative of invasive tumour, intraepithelial tumour, and normal adjacent epithelium were selected for analysis by in situ hybridisation.

Cases of condyloma accuminata and laryngeal papillomata containing HPV 6 or 11 and cervical SCC containing HPV 16 or 18 were chosen as positive control tissues. The human cell lines $\mathrm{CaSki}$ and $\mathrm{SiHa}$, both containing HPV 16 genome, and HeLa, containing HPV 18 , were also used as positive controls for DNA slot-blot analysis. All three cell lines were obtained from American Tissue Type Culture Collection, USA.

Plasmids containing HPV types $6,11,16$ and 18 DNA were kindly provided by Professor zur Hausen and Dr Gissmann (German Cancer Research Centre, Heidelberg, Federal Republic of Germany). ${ }^{16-19}$ HPV probes were obtained by digesting the plasmid DNA with $B a m H I$ for HPV 6, 11, 16, and EcoR I for HPV 18. The viral DNAs were labelled with digoxigenin for in situ hybridisation using a detection kit (Boehringer, Mannheim $\mathrm{GmbH}$, Pensberg, West Germany), or oligo-labelled for slot blot hybridisation according to the supplier's instructions (Bresatec, Australia).

\section{IN SITU HYBRIDISATION}

The method used was a modification of the one previously described.$^{20}$ Hybridisation was performed with digoxigenin-labelled probes at a final concentration of $200 \mathrm{ng} / \mathrm{ml}$ in $50 \%$ (v/v) deionised formamide, $10 \%(\mathrm{w} / \mathrm{v})$ dextran sulphate, $2 \times$ SSC ( $30 \mathrm{mM}$ sodium chloride, 3 $\mathrm{mM}$ sodium citrate) and $0 \cdot 2 \%$ dried milk powder at $42^{\circ} \mathrm{C}$ overnight.

Post-hybridisation wash included $2 \times$ SSC at $60^{\circ} \mathrm{C}$ for 10 minutes, followed by $0.2 \times$ SSC at $42^{\circ} \mathrm{C}$ for 10 minutes with stirring. For sections to be washed in low stringency, the initial temperature for washing was reduced to $45^{\circ} \mathrm{C}$.

Signal detection was performed using poly sheep anti-digoxigenin-Fab fragments conjugated to alkaline phosphatase (Boehringer, Mannhein, Biochema, Penzeberg, West Germany) according to the supplier's recommendations. define the extent of invasive tumour and
SLOT-BLOT ANALYSIS 2122

DNA $(5 \mu \mathrm{g})$ extracted from cryosections using proteinase $\mathrm{K}$ was blotted on to a nylon membrane (Genescreen Plus, Dupont, NEN Products, Boston, Massachusetts) according to the supplier's instructions.

The membranes were hybridised to the 
Figure 1 (A) Papilloma of larynx with strong signal in in situ hybridisation (see insert) for $H P V 11$

(haematoxylin and eosin). (B) Intraepithelial neoplasia of the oesophagus with no detectable signal in in situ hybridisation (see insert) for $H P V 11$

(haematoxylin and eosin).
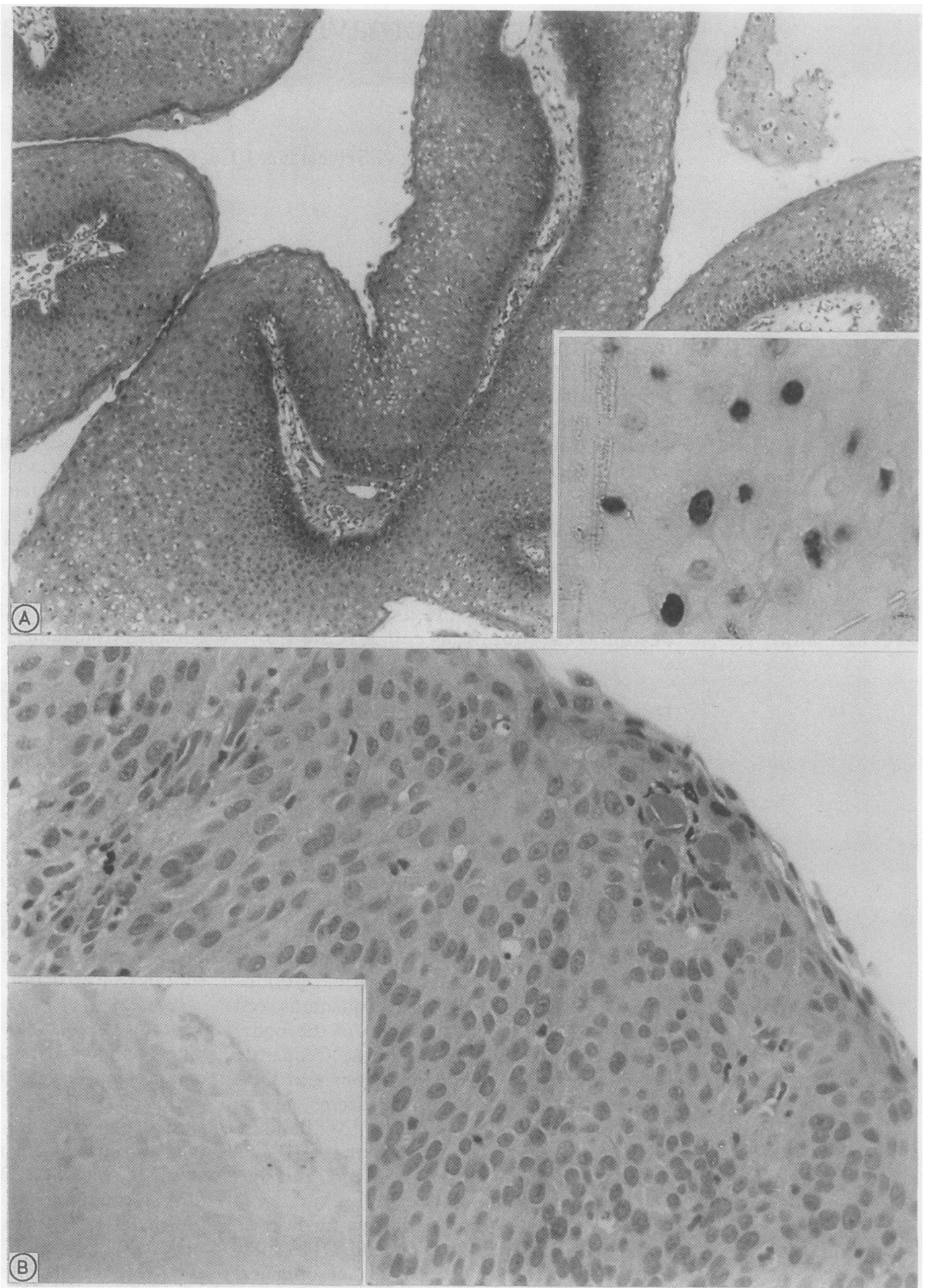

denatured ${ }^{32} \mathrm{p}$-oligo-labelled HPV DNA probe $(0.5-2 \mathrm{ng} / \mathrm{ml})$ in $50 \%$ formamide, $1 \mathrm{M} \mathrm{NaCl}$, $10 \%$ dextran sulphate, $1 \%$ sodium dodecyl sulphate, $0 \cdot 2 \%$ polyvinyl-pyrrolidone, $0 \cdot 2 \%$ Ficoll, $0 \cdot 2 \%$ bovine serum albumin, $50 \mathrm{mM}$ TRIS-HCl (pH 7.5), $0.1 \%$ sodium pyrophosphate (NaPPi) and denatured salmon sperm DNA at $42^{\circ} \mathrm{C}$ for 40 hours. The final wash of the membranes was in solution containing $0.2 \times \mathrm{SSC}, 0.1 \% \mathrm{NaPPi}, 0.1 \mathrm{mM}$ EDTA and $1 \%$ sodium dodecyl sulphate at $65^{\circ} \mathrm{C}$ for 40 minutes.

Autoradiography was carried out using an X-OMAT AR $X$-ray film (Kodak).

\section{Results}

IN SITU HYBRIDISATION

With post-hybridisation washing in high stringency, strong signal was detectable in the control tissues for each HPV type. Similar washing conditions gave no detectable signal in the cases tested. A representative pair of control condyloma and oesophageal SCC hybridised with HPV 11 probe is shown in fig 1 . When washing was performed in low stringency, there was still no signal in all of the cases tested and the background was the same between the sections hybridised to the HPV probes and the plasmid without the viral 

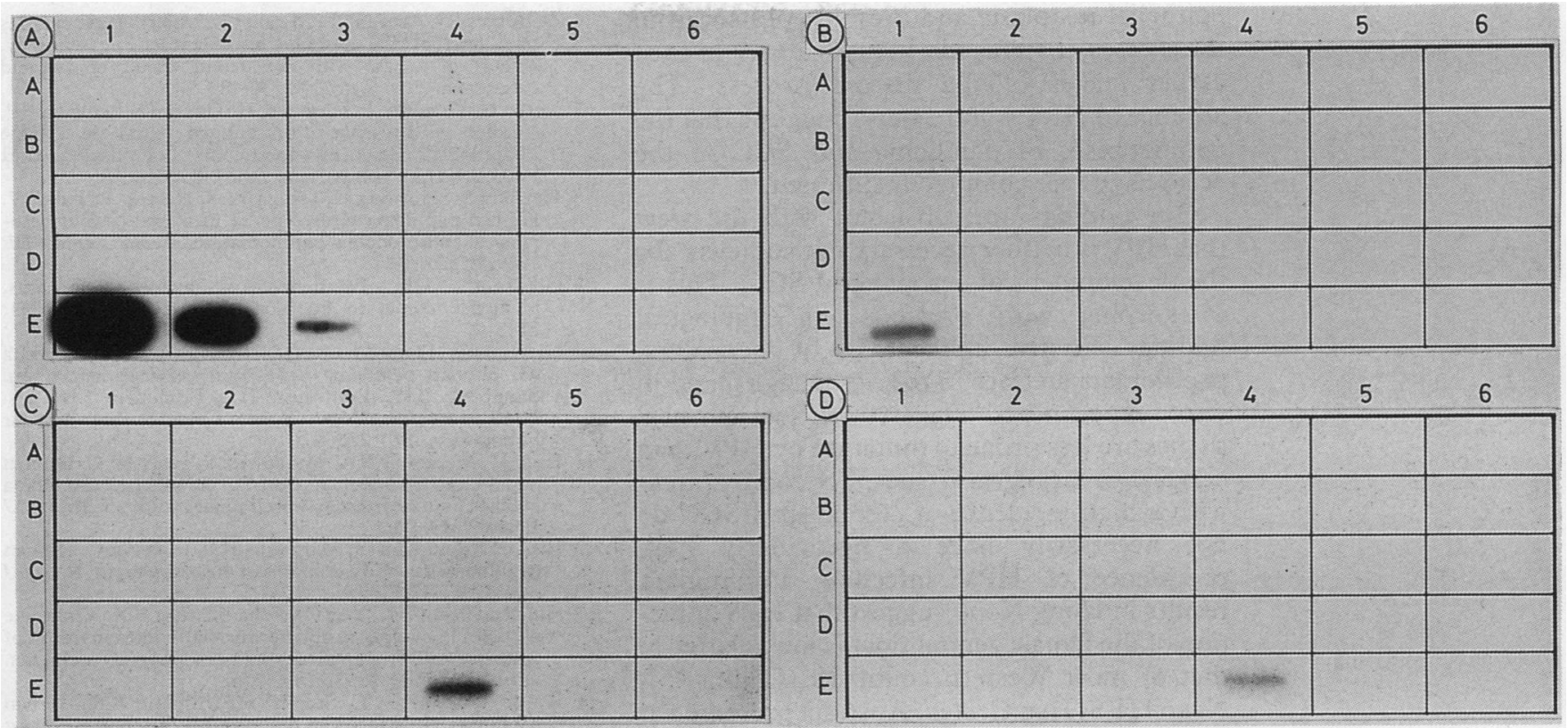

Figure 2 No signal was detected in DNA slot-blot using $5 \mu \mathrm{g}$ total DNA from each of the 21 cases of invasive carcinoma $(A, 1-6 ; B, 1-6 ; C, 1-6$ and $D, 1-3)$ :

(A) Hybridisation with HPV16, with $1 \mu \mathrm{g}, 100 \mathrm{ng}, 10 \mathrm{ng}, 1 \mathrm{ng}, 100 \mathrm{pg}$ and $10 \mathrm{pg}$ DNA from CaSki cell line (E, 1-6) as control.

(B) Hybridisation with HPV 18, with $1 \mathrm{\mu g}, 100 \mathrm{ng}, 10 \mathrm{ng}, 1 \mathrm{ng}, 100 \mathrm{pg}$ and $10 \mathrm{pg}$ of DNA from HeLa cell line (E, 1-6) as control.

(C) Hybridisation with HPV6, with $10 \mu \mathrm{gNA}$ from CaSki $(E, 1), \operatorname{SiHa}(E, 2), \mathrm{HeLa}(E, 3)$ and laryngeal papilloma $(E, 4)$ as controls.

(D) Hybridisation with HPV11, with $10 \mu \mathrm{gNA}$ from CaSki $(E, 1), \mathrm{SiHa}(E, 2), \mathrm{HeLa}(E, 3)$ and laryngeal papilloma $(E, 4)$ as controls.

inserts. Similar negativity was noted for the invasive carcinomas, intraepithelial neoplasia, and normal mucosa. This indicated that there were no focal collections of cells containing abundant virons of these HPV types.

\section{DNA SLOT-BLOT ANALYSIS}

By titrating the DNA extracted from cell lines, we determined our sensitivity in HPV detection. HPV 16 genome was detectable in $10 \mathrm{ng}$ of total DNA from CaSki cell lines but not in $5 \mu \mathrm{g}$ of total DNA from each of the cases when hybridised in the same conditions (fig 2A). As there was an average of 400-500 copies of HPV 16 per cell in CaSki cell lines, our DNA slotblot should be able to detect HPV 16 genome with a sensitivity of up to an average of one copy per cell. This was further supported by our ability to detect the genome in $2 \mu \mathrm{g}$ of total DNA from the SiHa cell line which contained one to two copies per cell. Similarly, HPV 18 genome was detectable in $1 \mu \mathrm{g}$ of total DNA from $\mathrm{HeLa}$ cell lines but not in $5 \mu \mathrm{g}$ total DNA from SCC (fig 2B). As HeLa cell lines contained four to 50 copies of viral genome per cell, we should have been able to detect HPV 18 genome with a sensitivity of up to $0 \cdot 8-10$ copies per cell in SCC.

HPV 6 or 11 genome was readily detectable in $5 \mu \mathrm{g}$ of total DNA from the cervical condylomata and laryngeal papillomata, but not in a similar amount of total DNA from the oesophageal SCC. As the copy numbers of viral genome in the condylomata and papillomata were unknown, the sensitivity for detection of HPV 6 and 11 was not determined (fig 2C, D). Our inability to detect any HPV genome of any type in the 21 cases studied indicated that either these HPV types were not present in the invasive tumours, or that, there were too few copies of the viral genome.

\section{Discussion}

SCC, the most common malignancy of the oesophagus, ${ }^{23}$ is common among Southern Chinese, and ranks fifth in the league table of deaths from cancer in Hong Kong. ${ }^{24}$ The recent interest in HPV and its association with cervical SCC has led to the investigation of its possible aetiological role at other sites of the body. As in cervical SCC, detection of viral genome has been reported in several other mucosal sites. ${ }^{1-4}$

Hille et al reported detection of HPV antigen by immunostaining oesophageal SCC in South African patients in about a third of the cases. ${ }^{12}$ HPV genome has been detected in three cases of oesophageal SCC in Australian patiènts by Kulski et al using filter in situ hybridisation with a probe mixture containing HPV ty'pes 11 , 13,16 and $18 .^{14}$ These workers found no detectable viral antigen in these cases, suggesting that detection of the genome is more sensitive than immunostaining.

By contrast, Kiyabu et al were unable to detect HPV 16 or 18 in invasive SCC of the oesophagus in North American patients using the polymerase chain reaction. ${ }^{4}$ The possible role of other types of the virus was not investigated, and no mention was made of intraepithelial neoplasia or areas of adjacent normal epithelium.

Our inability to detect the presence of HPV in cases of SCC of the oesophagus is in keeping with the findings of Kiyabu et al. ${ }^{4}$ Moreover, by performing in situ hybridisation, we can correlate histology with viral genome detection. As no HPV was detectable in intra- 
epithelial neoplasia and normal epithelium in these cases, it seems that virus is absent even at earlier stages of the disease process. The absence of HPV 6 and 11 also suggests that the pathogeneses of papilloma and SCC of the oesophagus are completely different.

Our findings are consistent with the view that HPV is neither necessary nor sufficient for the development of oesophageal SCC. This is in keeping with previous epidemiological findings. Firstly, unlike SCC of the cervix, papillomata are rare in the oesophagus, and in vitro experiments suggest that oesophageal tissues are less prone to mutation by HPV than cervical or laryngeal tissues. ${ }^{25}$ Secondly, areas with a high incidence of oesophageal SCC do not necessarily have a particularly high prevalence of HPV infection. Preliminary results in Hong Kong suggest that HPV infection of the female genital tract is low relative to that of most Western countries (Collins RJ, Ngan HYS, Hsu C, et al. Abstract presented at the thirty fourth annual scientific meeting of the Royal College of Pathologists of Australia, 1989), and yet we have a high incidence of cervical SCC. Thirdly, other environmental factors such as diet or exposure to chemical carcinogens are epidemiologically related to SCC of the oesophagus. It is, however, still possible for HPV to act as an additional promotor after tumour induction by these carcinogens. $^{2627}$

In conclusion, we were unable to detect HPV genome in oesophageal SCC in Hong Kong using techniques that could detect small copy number of virons in tumour cells. This strongly suggests that HPV does not have a similar role in SCC of the oesophagus as is the case in comparable malignancies of other mucosal sites.

We thank Mr SK Lau for his expert help in photography. The study is supported by a research grant from the University of Hong Kong.

1 de Villers EM. Heterogeneity of the human papillomavirus group. J Virol 1989;63:4898-903.

2 Gal AA, Meyer PR, Taylor CR. Papillomavirus antigens in anorectal condyloma and

3 Brandsma J, Abramson A, Sciubba J, Shan K Barrezueta N, Galli R. Papillomavirus infection of the nose. In: Galinberg BM, Brandsma JL, Taichman LB, eds. Papillomaviruses. New York: Cold Spring Harbor Papillomaviruses. New

4 Kiyabu MT, Shibata D, Arnheim N, Martin WJ, Fitzgibbons PL. Detection of human papillomavirus in formalin-fixed, invasive squamous carcinoma using the polymerase chain reaction. Am J Surg Pathol 1989;13:221-4.

5 Lowy DR. Clinical perspective-papillomavirus infection. In: Furth M, Greaves M, eds. Molecular diagnostics of human cancer. New York: Cold Spring Harbor Laboratory Press, 1989:183-6.
6 de Borges RJ, Acevedo F, Miralles E, Mijares P. Squamous papilloma of the oesophagus diagnosed by cytology. Report of a case with concurrent occult epidermoid carcinoma. Acta Cytol 1986;30:487-90.

7 Lesec G, Gogusev J, Fermaud H, Gorce D, Lemaitre JP, Verdier A. Presence d'un antigene viral de groupe "Papilloma" dans un condylome oesophagien chez l'homme. Gastroenterol Clin Biol 1985;9:166-8.

8 Hording M, Hording U, Daugaard S, Norrild B, Faber V. Human papilloma virus type 11 in a fatal case of oesophageal and bronchial papillomatosis. Scand J Infect Dis 1989;21:229-31.

9 Goldsmith MF. Papillomavirus invades esophagus, incidence seems to be increasing. JAMA 1984;251: 2185-7.

10 Gissmann L, Durst M, Oltersdorf T, von Knebel Doeberitz M. Human papillomaviruses and cervical cancer. In: Steinberg BM, Brandsma JL, Taichman LB, eds. Papillomaviruses. New York: Cold Spring Harbor Laboratory, 1987:275-80.

11 Hille JJ, Margolius KA, Markowitz S, Isaacson C. Human papillomavirus infection related to oesophageal carcinoma papillomavirus infection related to oesophageal carcinoma in black South Afric

12 Hille JJ, Markowitz S, Margolius KA, Isaacson C. Human papillomavirus and carcinoma of the oesophagus. $N$ Engl Med 1985;312:1707.

$13 \mathrm{Hu}$ ZL, Chang KL, Yen CX, Zha SC, Liu KX. Virus-like particles in cytoplasm and vermicellar bodies in nuclei of epithelial cells from patients with oesophageal carcinoma. Ultrastruct Pathol 1986;10:459-61.

14 Kulski J, Demeter T, Sterrett GF, Shilkin KB. Human papilloma virus DNA in oesophageal carcinoma. Lancet 1986;ii:683-4.

15 Syrianen S, Partanen P, Syrjanen K. Comparison of in-situ DNA hybridisation protocols using $35 \mathrm{~S}$-labeled and biotin-labeled probes in detection of human papilloma biotin-labeled probes in detection of human papilloma
virus DNA Sequences. In: Steinberg BM, Brandsma JL, virus DNA Sequences. In: Steinberg BM, Brandsma JL, Taichman LB, eds. Papillomaviruses. N

16 De Villiers EM, Gissmann L, Zur Hausen H. Molecula cloning of viral DNA from human genital warts. $J$ Viro 1981;40:932-5.

17 Gissman L, Diehl V, Schultz-Coulon HJ, Zur Hausen H. Molecular cloning and characterisation of human papilloma virus DNA derived from a laryngeal papilloma. J Virol 1982;44:393-400.

18 Durst $M$, Gissman L, Ikenberg $H$, Zur Hausen $H$. A papillomavirus DNA from a cervical carcinoma and its prevalence in cancer biopsy samples from different prevalence in cancer biopsy samples from different 1983;80:3812-5.

19 Boshart M, Gissman L, Ikenberg H, Kleinheinz A Scheurlen W, Zur Hausen H. A new type of papillomavirus DNA, its presence in genital cancer biopsies and in cell lines derived from cervical cancer. $E M B O J 1984 ; 3: 1151-7$.

20 Terry RM, Lewis FA, Griffiths S, Wells M, Bird CC. Demonstration of Human Papillomavirus types 6 and 11 in juvenile laryngeal papillomatosis by in-situ DNA hybridisation. J Pathol 1987;153:245-8.

21 Maniatis T, Fritsch EF, Sambrook J. Molecular cloning. A laboratory manual. New York: Cold Spring Harbour Laboratory, 1982.

22 Davis LG, Dibner MD, Battey JF. Basic methods in molecular biology. New York: Elsevier Science Publishing Co, Inc. 1986.

23 Ming SC. Tumours of the esophagus and stomach Atlas of tumour pathology. Fascicle 7. Washington, DC: Armed Forces Institute of Pathology, 1973.

24 Director of Medical and Health Services, Hong Kong. Hong Kong Annual Departmental Report. Hong Kong: HMSO, 1989.

25 JW Kreider, Howett MK, Stoler MH, Leure-Dupree AE, Lill NL, Zaino RJ. Tissue-specific expression of human papillomavirus type 11. In: Steinberg BM, Brandsma JL, papillomavirus type 11. In: Steinberg BM, Brandsma JL, Taichman LB, eds. Papillomaviruses.

26 Amtmann E, Randeria J, Wayss K. Interaction of papillomaviruses with carcinogens and tumor promotors. papillomaviruses with carcinogens and tumor promotors. In: Steinberg BM, Brandsma JL, Taichman LB, eds. Papillomaviruses. New $1987: 259-66$.

27 Jarrett WF. The Leeuwenhoek lecture, 1986. Environmental carcinogens and papillomaviruses in the pathogenesis of cancer. Proc $R$ Soc Lond 1987;231:1-11. 